University of Nebraska - Lincoln

DigitalCommons@University of Nebraska - Lincoln

Agronomy \& Horticulture -- Faculty Publications

Agronomy and Horticulture Department

6-1940

\title{
Occurrence of a Disease of Side-oats Grama
}

\author{
R. L. Fowler \\ J. E. Weaver \\ University of Nebraska-Lincoln
}

Follow this and additional works at: https://digitalcommons.unl.edu/agronomyfacpub

Part of the Plant Sciences Commons

Fowler, R. L. and Weaver, J. E., "Occurrence of a Disease of Side-oats Grama" (1940). Agronomy \& Horticulture -- Faculty Publications. 441.

https://digitalcommons.unl.edu/agronomyfacpub/441

This Article is brought to you for free and open access by the Agronomy and Horticulture Department at DigitalCommons@University of Nebraska - Lincoln. It has been accepted for inclusion in Agronomy \& Horticulture -Faculty Publications by an authorized administrator of DigitalCommons@University of Nebraska - Lincoln. 


\title{
Occurrence of a Disease of Side-oats Grama ${ }^{1}$
}

\author{
R. L. Fowler and J. E. Weaver
}

The beginning of a disease of Bouteloua curtipendula, first observed in 1937 but occurring in alarming proportions in 1939, is of much interest. The fact that this grass has increased greatly during the past six years, from a rank of seventh or eighth among dominants of true prairie to one of the two or three most important species, adds unusual economic interest. Moreover, side-oats grama not only has very wide distribution and is being grown abundantly in grass nurseries of the Soil Conservation Service but also it is one of the most drought-resistant among the best grasses for rejuvenating depleted pastures and reseeding abandoned lands. For these reasons, although the cause of the disease has not been determined, a rather complete account of its occurrence and increase seems warranted.

DISTRIBUTION AND FORMER ABUNDANCE OF SIDE-OATS GRAMA

Bouteloua curtipendula is very widely distributed in the United States and is much used for both hay and forage. It occurs more or less abundantly from Montana to Arizona and is of considerable importance throughout. It ranges eastward to the New England states and southeastward to South Carolina (Hitchcock 1935).

From 1929 to 1933 an extensive survey was made of the percentage composition of the components of true prairie. This study included portions of six states in the Missouri River valley covering a total area of 60,000 square miles (Weaver and Fitzpatrick 1932, 1934). The quadrat method was extensively employed. Among 180 meter quadrats in the little bluestem (Andropogon scoparius) type, side-oats grama occurred in 32 per cent and constituted but 0.6 per cent of the basal cover of vegetation. It was found in only 7 per cent of the 155 quadrats examined in the big bluestem (A.furcatus) type and composed but 0.1 per cent of the cover. Twenty-five samplings in the much less abundant needle grass type (Stipa spartea) revealed an occurrence of 32 per cent but this species constituted only 0.9 per cent of the total vegetation. From these data and extensive observations in the true prairie over the five year period, it was concluded (1932):

"Side-oats grama is scattered widely throughout the prairie in all types of situations, but rarely occurs in great abundance. The largest undisturbed area found that was controlled by this mid grass did not exceed a few square meters. It nearly always occurs as small, isolated, rather open tufts scattered among the other species. A 1 to 3 per cent mixture is common, even on uplands, and it may occur as abundantly as 10 per cent locally. Its habit approaches that of an interstitial species, and

${ }^{1}$ Contribution no. 124 from the Department of Botany, University of Nebraska. 
where there is disturbance, such as is caused by erosion on steep banks, etc., it frequently increases in abundance. Quadrats in old roads along ridges sometimes give an abundance ranging from 15 to 60 per cent. It withstands grazing rather well and increases in territory under moderate pasturing. Although nearly always represented in any considerable area, its importance is not great."

When the ravages of the great drought became apparent in 1934, it was decided to select for further study a small group of the 135 prairies formerly examined in western Iowa, where deterioration from drought was small, through southeastern Nebraska to north central Kansas, where drought-damage was very great (Weaver and Albertson 1936). At nine of these stations in Nebraska and Kansas a series of more than 100 permanent sample areas, mostly one square meter in size, was established. An exact record by means of stem counts has been made each year from 1936 to 1939 inclusive (Cf. Robertson 1939). The occurrence of the disease was first observed in these plots by Robertson in July, 193\%, in a prairie about 3 miles south of Montrose, Kansas, where it has steadily increased. In the meantime it has been found at many other stations.

INCREASE IN ABUNDANCE FOLLOWING DROUGHT

Great destruction of native grasslands resulted from the most severe drought ever recorded in the prairies of Nebraska and Kansas, especially in 1934 and 1936. All the grasses suffered some loss but especially those with relatively short root systems (4 feet or less in length), notably Andropogon scoparius, Koeleria cristata, Stipa spartea, and the invading Poa pratensis. Losses varied greatly, but at many of the stations under observation they ranged from 30 to 80 per cent or more. Side-oats grama also lost heavily but in general withstood drought better than the bluestems. Much soil was thus laid bare for invasion. Hordes of short-lived weeds and annual grasses predominated for a year or more, after which western wheat grass (Agropyron Smithii) increased at such a rate as literally to take over, in many prairies, most of the land formerly occupied by more mesic grasses.

The great outbreak and spread of wheat grass reached its peak in or before 1938. Since that time this species has still spread somewhat in places where its increase began later than in most prairies, but in nearly all it has waned markedly. This wave of wheat grass was followed closely in many prairies by a similar one of side-oats grama. This resulted from a reclaiming of much drought-denuded territory by side-oats, and by its migration into the wheat-grass area by a process of infiltration. Often it is the chief competitor of the wheat grass. The wide and rapid spread was largely a result of enormous crops of seedlings, which, once established, may develop bunches from 8 to 14 inches in diameter, but it was due partly 
to propagation by abundant rhizomes from 2 to 4 inches in length. In some of the prairies this grass now ranks only second in importance to wheat grass; in several it is among the three most abundant grasses; and even where it is of least occurrence it has increased many fold. For example, it now constitutes 40 and 60 per cent, respectively, of the vegetation of the prairies at Carlton and Nelson, Nebraska. This increase under these unusual conditions of intermittent drought has been accompanied by the occurrence and alarming increase of a diseased condition.

EFFECTS OF THE DISEASE AND ITS RATE OF INCREASE

First noted in 1937, the diseased condition was also noticed near Nelson, Nebraska, the following year. During 1939, it was of wide occurrence, being found not only at Valparaiso, Hebron, and Carlton in southeastern Nebraska but also as far west as Holdrege and Edison. In Kansas it occurred at Belleville and as far southeast as Melvern, south of Topeka. The diseased plants occur in scattered patches, sometimes throughout the prairie, but are more prevalent in drier places. The size of the patches varies from a few square inches to one or more square rods, the destruction wrought often including two-thirds of the plants and being so great that the larger affected areas are conspicuous at a distance of several rods.

Symptoms of the disease, based on field observations, include the appearance in early spring of rosette-like clumps or portions of bunches which contain tillers in very large numbers, often 70 or more per square centimeter. The rosetted plants or portions of plants do not elongate normally; many are only an inch or two high, and the foliage seldom attains a height exceeding 3 or 4 inches. The stem bases develop a distinctly reddish color. The leaves are dwarfed to only one-third or less their usual width. The general appearance reminds one strongly of mosaic (virus) disease of wheat (McKinney 1937). The leaves are yellowishgreen in color and turn brown after death. The brown color is very different from that of normal dead leaves, which bleach almost white. Flowerstalks, if any, show marked reduction in number, often to 20 per cent, and attain only about two-thirds the normal height (figures 1 and 2). Death and browning of small bunches or portions of larger ones may occur early in June, but later many more plants or other parts of the bunches become affected. In the Nelson prairie, which is composed of 60 per cent side-oats grama, approximately 30 per cent of the plants throughout the prairie were diseased (figure 3 ).

IMPORTANCE OF THE GRASS IN RANGES AND IN SOIL CONSERVATION

This is one of the largest species of grama grass. It is a mid grass of the bunch habit despite the presence of rhizomes, and reaches a height of from 1 to 4 feet. The plants produce much foliage, and because of their leafiness the species is prized both for forage and hay. Although it fur- 

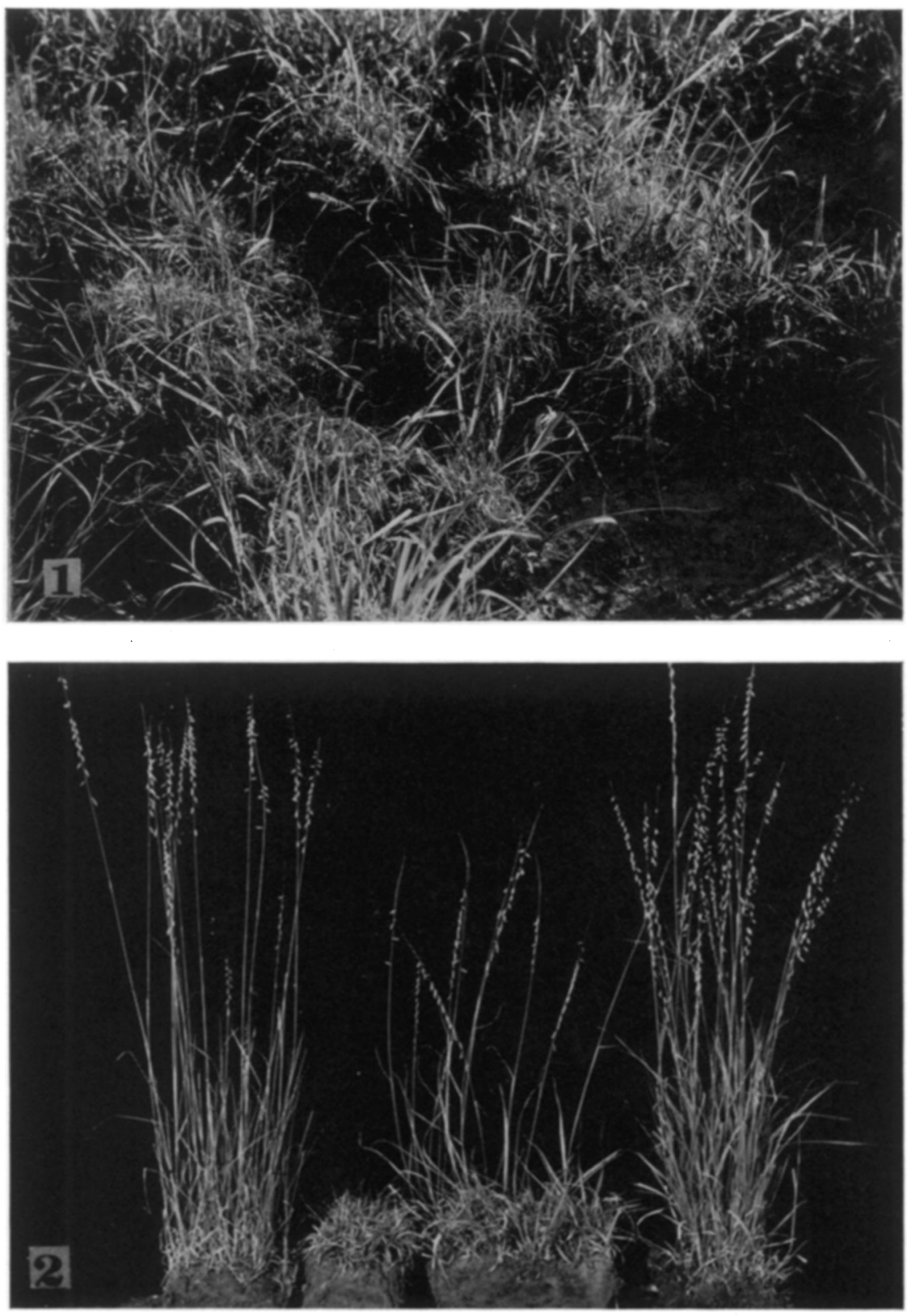

Fig. 1. Detail of a small portion of a widely affected area of pure side-oats grama at Nelson, Nebraska, on August 15, 1939. Note the abundant, narrow, dead leaves and the few remaining broad and erect live ones. There are no flower stalks.

Fig. 2. Normal healthy plants of side-oats grama (ends) about 3 feet tall and two groups of diseased ones (center) with short, fine, dead leaves and few or no flower stalks. August 15, 1939. 


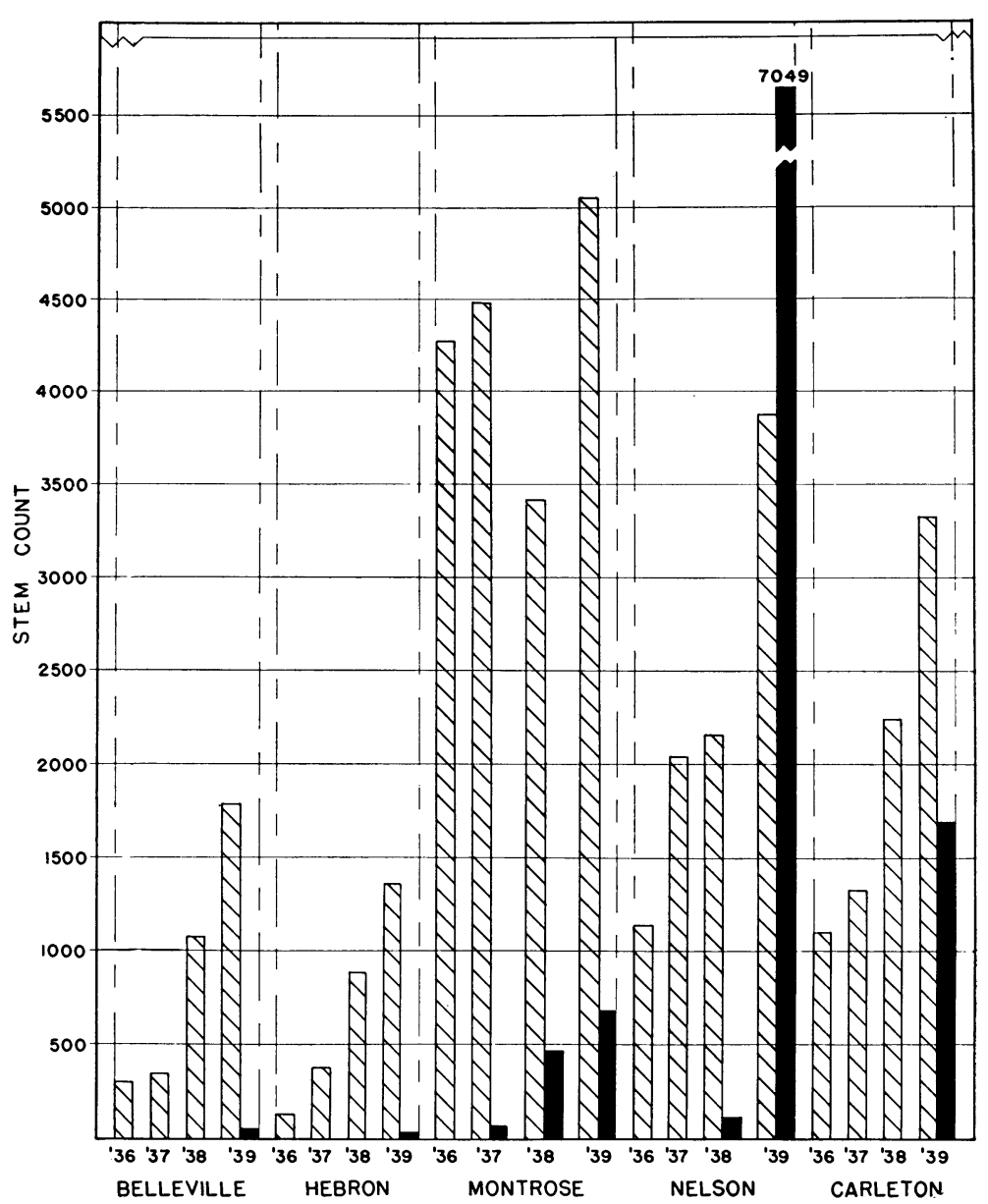

Fig. 3. Rate of increase in number of normal stems of side-oats grama (right hatch) and diseased stems (black) during 4 years. These data are from permanent meter quadrats which contained diseased plants during the period of observation. Percentage of diseased stems in 1939 was 2.9 at Belleville, 2.3 at Hebron, and 33.6 at Carleton. At Montrose, diseased stems were 1.4 per cent in 1937, 12.1 per cent in 1938, and 11.8 per cent in 1939. At Nelson 5.2 per cent were diseased in 1938 but 64.5 per cent in 1939 .

nishes forage both summer and winter, the dried grass is of rather low palatability compared with many other gramas. Nor does the good palatability of the green plants include the stems, which are rather inedible and often left standing after the foliage has been eaten.

Its wide range of distribution shows its considerable adaptability. It grows well, and often in pure stands, on dry steep banks or in thin, rocky soil or as a component of luxuriant prairie on fertile loams. This wide adaptability to habitat, its large size, vigorous, rather early growth, drought resistance, and good seeding habits combine to make it a desirable 
grass for domestication and use in grass mixtures in reseeding ranges and abandoned lands. It is known as a grass that will control erosion, the strongly branched, deep root system firmly anchoring the plants in the dense sod which develops under artificial seeding. It is recommended in a mixture with blue grama (Bouteloua gracilis) and buffalo grass (Buchloë dactyloides) for growth on drought-bared lands of the semiarid west (Cornelius 1939).

As pointed out by Cardon (1937), the extent to which disease may affect the carrying capacity and nutritive value of pasture grasses has not yet been determined on American ranges. When further studies are made it may be found that disease resistance will take on greater importance, with resistance to winter killing, to insect injury, and to drought.

Whether this disease is caused by insect damage, fungi, bacteria, a virus, or is physiological in character is unknown. ${ }^{1}$ It seems reasonable that the extreme conditions of environment resulting from the years of drought may have been a contributing factor. The normal mulch of litter has often been replaced by bare soil (figure 1 ). The wide spacing of the plants permits full insolation to their base, and results in extremes of soil temperatures. The great quantities of dead underground materials from vegetation overcome by drought have temporarily modified organic content of soil, as is witnessed by a highly abnormal number of saprophytic fungi during wet weather. Other factors, notably extremes in water content of soil, have been equally pronounced.

The University of Nebraska

Lincoln, Nebraska

\section{Literature Cited}

Cardon, P. V. 1937. Plant breeding in relation to pasture improvement. Plenary papers. Fourth International Grassland Congress, Aberystwyth, Great Britain. pp. 31-39.

Cornelius, D. R. 1939. Side-oats grama for erosion control. Soil Conservation 5: $3-6$.

Hitcheock, A. S. 1935. Manual of the grasses of the United States. U. S. Dept. Agr., Misc. Pub. No. 200.

McKinney, H. H. 1937. Mosaic diseases of wheat and related cereals. U. S. Dept. Agr., Circ. 442.

Robertson, J. H. 1939. A quantitative study of true-prairie vegetation after three years of extreme drought. Ecol. Monogr. 9: 433-492.

Weaver, J. E. \& Albertson, F. W. 1936. Effects of the great drought on the prairies of Iowa, Nebraska, and Kansas. Ecology 17: 567-639.

Weaver, J. E. \& Fitzpatrick, T. J. 1932. Ecology and relative importance of the dominants of tall-grass prairie. Bot. Gaz. 93: 113-150.

Weaver, J. E. \& Fitzpatrick, T. J. 1934. The Prairie. Ecol. Monogr. 4: 109-295.

1 Research on the identification of this disease from plants furnished by the writers is being conducted by Dr. J. H. Jensen, University of Nebraska, College of Agriculture. 